\title{
Statement from Hiroshima City University
}

\author{
Shin'ichi Wakabayashi ${ }^{1}$
}

Published online: 6 November 2019

(c) European Consortium for Political Research 2019

We would like to express our serious concerns over the article entitled "At the intersection of nationalism, incompetence and money: Mikyoung Kim versus Hiroshima City University of Japan," which was published online in European Political Science on 25 May 2018. The article was based on demonstrably false accounts, and does severely impair the credibility and reputation of our university, Hiroshima City University.

It is true that our university penalised Dr. Mikyoung Kim with disciplinary dismissal on 17 March 2017, following which Dr. Kim brought a lawsuit in order to demand the cancellation of the decision.

However, the reason for the dismissal can never be construed as a violation of academic freedom, gender-based discrimination, or racism, as she claims. Our university absolutely respects the academic freedom and political beliefs of each faculty member and therefore has never and will never dismiss any of them on the ground of such matters.

The most significant reason for her dismissal was the fact that, against the formally approved plan of conducting research at Cambridge University in the UK during her one-year research leave, she in fact never went to the UK and instead stayed in South Korea. To falsely support this deception that she had spent her research leave in Cambridge, she committed a number of forgeries and other acts including: explaining false accounts by e-mail; compiling and submitting a report to our university, explaining false accounts; forging her passport as if the Heathrow immigration stamp had been stamped on it, and submitting its copy to our university; forging a letter as if it was written and signed by a professor from Cambridge University, and submitting it to our university; receiving refunds by submitting flight tickets and forged boarding passes between Seoul and London which she had actually cancelled immediately after purchasing and printing the e-tickets and receipts; and forging immigration records, which were supposed to be official documents issued by the government of the Republic of Korea, and submitting them to our university.

This comment refers to the article available at https://doi.org/10.1057/s41304-018-0169-4.

Shin'ichi Wakabayashi

kikaku@m.hiroshima-cu.ac.jp

1 Hiroshima City University, Hiroshima, Japan 
We regarded her acts as providing that she could not be trusted and was not qualified to be a university faculty member, no matter what achievements she made as a researcher.

Our particular concerns are with two points: false accounts throughout the article, and severe disgrace to our university and colleagues.

1. False accounts throughout the article:

The article contains a number of false accounts. For example, contrary to what Dr. Mikyoung Kim discusses (p. 4), our university never sent "threatening" messages to the media and her "supporters" in an attempt to argue against them.

Dr. Kim wrote that she forged official documents such as boarding passes and immigration stamps because our university "ordered [her] to submit those specific documents" (p. 3). Our university never orders our colleagues to forge official documents, and that is common sense for any recognised and accredited university. We ask her to submit, for example, boarding passes for flights between Seoul and London because we simply believed her account that she had conducted research in the UK. And it is normal for a university to ask its staff members for such documents when they go on to research trips or leave to verify compensated expenditures.

Dr. Kim also states that "the police could not find any criminal intent [on her part, and]... suspected HCU [our university] of fabricating her criminality..." (p. 3). The prosecutors (not the police) indeed decided on the suspension of indictment. However, the decision was made not because they could not find her conduct criminal, but because the prosecutors decided not to file charges based on Article 248 of the Code of Criminal Procedure of Japan, and her criminality itself was confirmed. It should be stressed once again that the prosecutors decided on the suspension of indictment, but that does not mean that Dr. Kim was innocent as she claims.

2. Disgrace to our university and colleagues:

The article disgraces our university and some staff members by stating false accounts which cannot be overlooked. For example, our university never and will never discriminate (not to mention dismiss) our colleagues on the ground of gender, ethnicity or research topics, as she claims on p. 4.

Moreover, Dr. Kim's defamation in the article against her former senior, Dr. Gen Kikkawa, cannot be overlooked either. He never "declared his allegiance to PM Abe," "actively utilised the classroom to promote Japan's rearmament," or "manipulated hiring and firing processes by replacing existing peace researchers with his hawkish colleagues" (p. 6). Dr. Kikkawa is a well-known, highly acclaimed scholar of international politics who strives for realising world peace. And Dr. Kim's accounts are nothing but a serious slander against Dr. Kikkawa which are not at all based on fact and not substantiated beyond the subjective complaints of Dr. Kim.

Shin'ichi Wakabayashi, Ph.D.

President of Hiroshima City University 
Shin'ichi Wakabayashi received B.E. (1979), M.E. (1981), and Ph.D. (1984) in systems engineering from Hiroshima University. Prior to his professorship at the Graduate School of Information Sciences, Hiroshima City University, in 2003, he has served, among others, as Associate Professor at the Faculty of Engineering, Hiroshima University, from 1988 to 2003. In 2019, he assumed the posts of Board Chair and President of Hiroshima City University. 